ARTICLE

DOI: $10.1057 /$ s41599-018-0085-9

\title{
From associations to action: mental health and the patient politics of subsidiarity in Scotland
}

Mark Gallagher ${ }^{1}$

\begin{abstract}
In times of economic hardship public mental healthcare suffers a double disservice. On the one hand, it faces a diminution of existing resource, and on the other, it is met with vastly increased demand. The damage done to already hard-pressed public services during economic crises is often most keenly felt by those at the receiving end of statutory health and welfare provisions. When public services are deemed by its principal recipients to be no longer fit for purpose, it is unsurprising that they, along with others, look to agencies other than the state to meet their needs. In the final year of the 1970s, a decade in which Great Britain became the 'sick man of Europe', while Margaret Thatcher moved into 10 Downing Street, a new mental health organisation came into being in Scotland. Glasgow Association for Mental Health (GAMH) and a group of patients' social clubs called LINK clubs joined to form LINK/GAMH. In a climate of great social and economic upheaval during the 1980s, LINK/GAMH received substantial Urban Aid funding to support those suffering from mental illness. Motivated by principles of voluntary association, self-help and mutual aid, LINK/GAMH sought to 'cater for needs, and encourage aspirations, which are not and perhaps should not be met, or promoted by Statutory Welfare Agencies'. This article examines how the relationship between socioeconomic factors and mental health was understood by LINK/GAMH and how this informed the development of a resource centre, a rehabilitation programme and political campaigning by psychiatric patients. By focusing upon the activities of LINK/GAMH in the 1970s and 1980s, drawing on archival evidence and oral testimony, it will be argued that the concepts of solidarity and subsidiarity were embedded in the practices of patient associations. This study will show that through the development of relationships of solidarity and subsidiarity, across local, national and international boundaries, patient associations such as LINK/GAMH and their allies redefined a normative conception of the 'sick role', reclaiming civic selfhood and political agency for psychiatric patients.
\end{abstract}

\footnotetext{
${ }^{1}$ University of Glasgow, Glasgow, UK. Correspondence and requests for materials should be addressed to M.G. (email: Mark.Gallagher@glasgow.ac.uk)
} 


\section{Introduction}

$\mathrm{n}$ the 1970s, a decade in which trade union membership peaked in the UK, Mental Patients Unions (MPUs) emerged across the country, mainly in industrial towns and cities, to challenge the ways in which those diagnosed with mental illness were treated and governed. By 1974 a Federation of Mental Patients Unions was established in an attempt to coordinate and link these local unions together, while affording each group the autonomy to pursue its own local and particular objectives. By the end of the decade, however, the MPU movement had petered out and only one of the unions survived in modified form beyond the 1980s. Former MPU member Andrew Roberts has argued that Scotland pioneered the MPU movement in the UK. Moreover, he argues that, 'at least twice in as many decades it was Scottish patients who put their full force on the lever of history' (Roberts, 2009, p 16). As Roberts notes, the 'founding inspiration' for the first MPU in the UK, the Scottish Union of Mental Patients (SUMP), was Archie Meek, a 91-year-old patient of Hartwood Hospital (see Gallagher, 2017). Roberts (2009, p 17) suggests that 'the mainspring of any social movement is solidarity'. 'Archie's call', says Roberts, 'was a call to solidarity' ( $p$ 17). The contention here is that subsidiarity was also an important principle guiding the practices of collective action by psychiatric patients in Scotland, and particularly so for the leading Scottish group of the second wave of UK patient action in the 1980s.

Whilst not exclusive to Catholic Social Teaching-its origins can be traced to Aristotle's ethics and political philosophy-the principle of subsidiarity is most explicitly and clearly articulated and elaborated in various Papal encyclicals of the Catholic Church (Aroney, 2014; Brennan, 2014). It is defined in the Oxford English Dictionary as '(in politics) the principle that a central authority should have a subsidiary function, performing only those tasks which cannot be performed at a more local level' (https://en.oxforddictionaries.com/definition/subsidiarity). Subsidiarity is a structural principle of justice concerned with the legitimate distribution and balance of powers, social governance and responsibility in society. It has a dual function as an organizational principle and as a norm of social and economic justice (Schumacher, 1989, pp 260-261). In his encyclical Caritas in Veritate (Charity in Truth) Pope Benedict XVI (2009) wrote that 'the principle of subsidiarity must remain closely linked to the principle of solidarity and vice versa, since the former without the latter gives way to social privatism, while the latter without the former gives way to paternalistic social assistance that is demeaning to those in need'. This statement implies that the interlocking principles of solidarity and subsidiarity permit a path between extremes of competitive individualism and centralized bureaucratic statism. Foundational to the principles of subsidiarity and solidarity is the value and dignity of the individual person. According to John Finnis,

[The] principle is one of justice. It affirms that the proper function of association is to help the participants in the association to help themselves or, more precisely, to constitute themselves through the individual initiatives of choosing commitments (including commitments to friendship and other forms of association) and of realizing these commitments through personal inventiveness and effort in projects (many of which will, of course, be co-operative in execution and even communal in purpose). (Finnis, 2011, p 146).

The principle requires that people have a right to participate in the decisions that affect their lives and that such decisions should be made at the most immediate or local level consistent with their resolution. But it is also concerned with human beings as naturally social beings, who depend upon reciprocal relationships and associations with others, in order to flourish as individuals and to pursue the common good. Pope Benedict XVI (2009) has emphasized that 'subsidiarity respects personal dignity by recognizing in the person a subject who is always capable of giving something to others'. Finnis elaborates this source of the principle of subsidiarity, highlighting that Aristotelian method involves reasoning from human needs:

Human good requires not only that one receive and experience benefits or desirable states; it requires that one do certain things, that one should act, with integrity and authenticity; if one can obtain the desirable objects and experiences through one's own action, so much the better. Only in action (in the broad sense that includes the investigation and contemplation of truth) does one fully participate in human goods. One cannot-no one canspend all one's time, in all one's associations, leading and taking initiatives; but anyone who is never more than a cog in big wheels turned by others is denied participation in an important aspect of human well-being (Finnis, 2011, p 147).

Human beings are by nature social and political animals, yet there are social and economic circumstances and forms of relations engendered in modern liberal societies which leave human beings powerless, isolated and alienated, abstracted from community ties, belonging or membership, 'leaving virtually only individuals and the state' as the principal social actors (Pius XI, 1931; Herbert, 2011, p 251). Social cooperation and participation by persons in practice-based communities and intermediate civil associations, like clubs, unions and societies, allows individuals to realise their potential as social beings with the capacity to give, as well as to receive, and to pursue their own individual interests in ways compatible with the common good.

Andrew Roberts notes that the Mental Patients Unions of the 1970 s 'were associations of mental patients (and/or ex-patients) working for their common good' (Survivors History, 2017). In his encyclical Mater et Magistra (Mother and Teacher), Pope John XXIII (1961) defined the common good, under a section headed 'Proper Balance Necessary', as 'all those social conditions which favour the full development of the human personality'. While subsidiarity can be seen primarily as a principle of constraint on the activity of centralized or higher authorities interfering in the semi-autonomous activities of civil associations and the individuals who compose them, it also contains an element that requires higher level political authorities to support those of a lower order when necessary, to help their members, enabling them to pursue self-constituting activities, with a view to the common good (Brennan, 2014; Bogg, 2016). According to the principle of subsidiarity, decisions should be made at the lowest level possible and the highest level necessary. This means that there is a role for higher authorities such as the state in providing positive support to subsidiary associations, but that this should be done with a view to preserving the dignity of the individual person and 'ensuring that citizens engage in self-constituting activities, realizing their capacities as fully as possible' (Bogg, 2016, p 1). The Latin word sub-sidium referred to the third line of reserve soldiers in the Roman army, who were called upon only when the first and second lines of troops in the order of battle proved insufficient (Finnis, 2016, p 140). The word came to mean help, assistance, aid, a support which under ideal circumstances would not be necessary (Finnis, 2016, p 140).

Writing in the 1950s sociologist Talcott Parsons articulated a normative conception of the 'sick role' of the patient, 'which urged upon the laity submission, cognitive as well as bodily, to the authority of the state licensed physician' (Nicolson, 2002, p 640). 
To put it in simple terms, the 'sick role' implied that patients, especially psychiatric ones, should simply do what they are told by the technical experts sanctioned by the state, with little or no room for a dynamic relation involving shared decision making or cooperative deliberation. According to Parsons'conception

the two most dangerous potentialities, namely group formation and successful establishment of the claim to legitimacy, are avoided. The sick are tied up, not with other deviants to form a sub-culture of the sick, but each with a group of the non-sick, his personal circle and, above all, physicians [...] deprived of the possibility of forming a solidary collectivity (Parsons, 1951, p 477).

Contrary to Parsons' conception of the passive submission and individualization of patients in the paternalistic 'sick role', from the mid-twentieth century onwards, a sense of solidarity and a 'non-deferential collective identity amongst the disabled and chronic sick' formed, and patient-led campaign groups emerged across a number of western nations to challenge medical authority and campaign for reform to health services, often establishing sub-cultures of the sick (Nicolson and Lowis, 2002, p 173; see also Burnham, 2012). These included groups of psychiatric patients and ex-patients. The politics of mental health in the UK were shaped by many factors, including socio-economic circumstances and transformations in national and local mental health associations, voluntary organisations with which psychiatric patients increasingly came into contact from the 1970s. These intermediary organisations became increasingly influential around this time as they responded to deficits in statutory mental health services, adopting the roles of advocate for the mentally ill, provider of social support and facilitator of pressure-group activity.

Against a backdrop of industrial strife at home and an oil crisis prompted by conflict in the Middle East, the economic problems of the UK mounted during the 1970s. After devaluation of the pound in 1976, the then Labour administration was forced to make substantial cuts to public expenditure when an emergency loan was made by the International Monetary Fund (IMF). Great Britain had become the 'the sick man of Europe'. A fiscal crisis of the state had contributed to financial stringency in relation to the provision of public services, including mental health services, which anyway had traditionally been accorded a low priority for resource allocation. After the IMF crisis and the election of the Conservative government in 1979 there was a shift in UK economic policy away from securing full employment and social welfare, towards control of inflation and expenditure. In these social and economic circumstances, with statutory mental health services under-staffed, over-stretched and under-resourced, new voluntary associations came into existence, and long-established mental health charities shifted the focus of their activities to address the social and economic needs of those suffering from mental illness.

There are parallels between then and now. Just as decades of post-war deindustrialization led to a crisis of unemployment and social dislocation in the 1980 s, today we are still coming to terms with the repercussions of the global financial crash of 2008 and the cuts to public expenditure which followed taxpayers' rescue of the financial sector (Tomlinson, 2016). By reflecting upon the collective action of psychiatric patients in the past, and the principles embedded in their practices, we can remind ourselves how the principle of subsidiarity can guide action today, in pursuit of the common good, and in resistance to those forces of liberal individualism buttressed and emboldened by the imposing market state which emerged in the 1980s. This article will examine how the relationship between socioeconomic factors and mental health was understood by the Glasgow-based mental health association, LINK/GAMH, and how this informed the development of a resource centre, a rehabilitation programme and political campaigning by psychiatric patients. By focusing upon the activities of LINK/GAMH in the 1970s and 1980s, drawing upon archival evidence and oral testimony, it will be argued that the concept of subsidiarity was embedded in the practices of LINK/GAMH and in patient associations more broadly. This study will show that through the development of relationships across local, national and international boundaries, patient associations such as LINK/GAMH and their allies attempted to redefine a normative conception of the 'sick role', reclaiming civic selfhood and political agency for psychiatric patients.

\section{Stands Scotland where it did?: the emergence of LINK/ GAMH}

In the two decades following the 1960 Mental Health (Scotland) Act, and the call in 1961 by UK Minister for Health Enoch Powell for psychiatric hospital closures, there was little change to the overall shape of the hospital-dominated mental health service in Scotland. Despite a substantial top-down reorganisation of the NHS in Scotland in 1972, and the passing of the Mental Health (Scotland) Act in 1984, a community mental health service for Scotland was still more aspiration than reality. In a broad survey of the field of mental health in the UK between the Mental Health Acts of 1959 and 1983 in England and Wales, and the Acts of 1960 and 1984 in Scotland, Martin (1984, p 66) asked, 'Stands Scotland where it did?'. His study is one of a few exceptions in the historiography of post-war mental health services for the attention it gives to Scotland and its recognition of significant 'Anglo-Scottish differentiation' within the union state (see also Long, 2017). Martin, then Professor of Social Administration at the University of Glasgow, found that little had changed during this period in mental health services in Scotland compared with the rest of the UK. By 1985 there remained proportionately twice as many people in Scotland under inpatient care as there was in England (Barham, 1997, p 36). Martin (1984, pp 68-71) noted that compared with England the development of mental health services in Scotland had not kept pace in the provision of day hospital facilities, specialized local authority social work services, and general hospital provision for psychiatric patients.

In the 1970s and 1980s Scotland had higher bed numbers, higher overall admission rates and longer average length of stays in hospital compared with the rest of the UK. The fact that there had been no equivalent in Scotland of the 1975 White Paper for England and Wales, Better Services for the Mentally Ill, was indicative of lack of public debate on mental health and what Martin (1984, p 72) described as 'an excess of complacency and a lack of self-examination in the central department and in the relevant professions' in Scotland. A report published by the Mental Welfare Commission for Scotland (MWCS, 1975, p 5) No Place to Go found that 'the provision of suitable accommodation outwith hospital for such patients proceeds at a distressingly slow rate [...] Too many patients remain in hospital because they have no place to go'. Mental health services in Scotland suffered from inadequate financial investment, and there was a lack of after-care provision and housing options. A 1981 MWCS report, Does the Patient Come First?, also noted that because of problems of 'interprofessional rivalry' and 'unreasonable tension between employing authorities and staff [...] there is a real danger that [...] the welfare of the patient [...] may be overlooked'. In the same report, reference was made to the ongoing injustice of patients in mental hospitals with no private address outside hospital being denied the right to vote, commenting that 'this is bitterly resented by 
many patients who, although they suffer from mental disorder, are perfectly fit to vote' (MWCS, 1981, p 40).

By the end of the 1980s the voluntary sector had become an increasingly significant, though small, part of the social organisation of mental health care in Scotland and a critical voice in debates over the future direction of mental health services (Drucker, 1986; 1987a, b). Mental health associations emphasized that 'voluntary organisations offer services which tend not to be undertaken by statutory bodies' (Maxwell, 1987, p 45) One such organization was LINK/GAMH, formed in Glasgow 1979 by a psychiatric social worker, Huw Lloyd-Richards. LINK Clubs were initially conceived as self-help groups and social clubs for psychiatric patients, and the first of the groups started around 1975. In the beginning they got a room in the basement of the Douglas Inch clinic for Forensic Psychiatry where they were supported by the unit's head, Peter Whatmore. Richards remarked that it was 'strange for a radical organization to be squatting in a forensic psychiatry unit' (Richards, 2017). In 1978 Richards brought together a group of people at the Glasgow Council for Voluntary Services (GCVS), establishing the Glasgow Association for Mental Health (GAMH) to provide social support services to psychiatric patients and ex-patients. GAMH had its first office in the Department for Social Administration at the University of Glasgow headed by Professor F.M. Martin, who was also a supporter. GAMH received substantial Urban Aid funding ( $£ 50 \mathrm{~K}+)$ for 'areas of multiple deprivation', mediated through the Regional Council (Gulstad, 1987, p 15). This funding was intended 'to set up and fund GAMH', not for the LINK clubs, and had no patient control associated with the use of the funds (Richards, 2017). Richards recounts how he 'connived at the first inaugural AGM with the LINK members to propose a constitutional amendment changing the title of the organization from GAMH to LINK/ GAMH' (Richards, 2017). This action, he says, 'created a real user-led (if not totally controlled) mental health organisation and LINK basically got the money and worked in a partnership with the formal GAMH structures' (Richards, 2017). He reveals that he 'finessed this', but 'was never forgiven for outwitting the Region' (Richards, 2017). He was fortunate to have found at GCVS, 'a conduit' to Strathclyde Regional Council social work department, which also 'disliked' LINK/GAMH. Richards 'was asked to appear before the Deputy Director of Social Work' to explain himself on the matter of the LINK/GAMH merger and the use of the funds: 'I simply said that I felt I could not stand in the way of democratic empowerment and assured him that I would make sure that everything was under control!' (Richards, 2017).

LINK/GAMH claimed that the voluntary sector 'acts as a catalyst for producing change; as guardian of the interests of patients and their families; as a lobby to secure resources; as a provider of innovative services' (Martin, 1984, p 164). The organization set its sights on these objectives at the beginning of the 1980s in an economic climate which was not favourable to claims to resources for the care of the mentally ill. It was the absence of day care and other community based mental health services which prompted LINK/GAMH to develop a 'springboard' programme which aimed to promote 'optimum recovery from the effects of mental illness and social distress and at encouraging independent living using available community resources' (Richards, 1983). Writing of the state of mental health services in Glasgow, Richards (1983) remarked that there are 'few projects which have grown out of local community activity and a notable absence of campaigning activity and advocacy in the mental health field'. A community development approach was adopted at LINK/GAMH and participants were encouraged to think of themselves as responsible and critical participants in, not passive recipients of, services. Richards (2017) comments that he worked in the "way of "servant leadership"' with the LINK club members, 'to see if we could make the waves together'. This approach challenged the passive 'sick role' that state-sanctioned medicine had allotted to patients, by encouraging them to become self-reflective and active citizens. LINK club member Betty Hannah described how in our self-help groups we find a listening ear and the support we need':

Since coming to LINK/GAMH I have taken part in many different things of interest. A course on advocacy and empowerment has given me much to strive for-to be able to help myself and to represent the views of others who feel unable to do so. Our group training serves to show the need for support both for ourselves and for each other [...] Similarly in our action group we can plan for the futurehoping to see some of our ideas become reality (Hannah, 1990, p 10).

The organization's Advice and Resource Centre offered individuals 'time, a place and skilled help to develop self-confidence, through setting goals around life issues' (Richards, 1983). The recovery programme involved group work, role play and discussion, as well as options of music, drama and art work. Workshops were held on social and interpersonal skills, housing and welfare rights, occupation, work and leisure. They set up 'programmes of group listening, social contact, food and games' and 'fostered friendships and shared experiences' (Richards, 2017). The centre was independent of existing psychiatric facilities and located close to the centre of Glasgow. By 1983 there were nine LINK clubs across Glasgow and a LINK Forum was established, to which the individual clubs elected representatives. The Forum was created to coordinate club activities and 'strengthen the voice of the consumer within the Association' (Richards, 1983). It aimed to promote the principle of self-help among people with mental health problems and to educate professionals and the public about mental illness (Richards, 1983). For Richards, 'voluntary and self-help projects' such as LINK/ GAMH

represent the capacity that sufferers of a range of problems, and their relatives, have to come together for support, mutual aid, problem-sharing and solving [...] These projects represent an ever growing voluntary sector network which closes the gap between those who have been ill, injured or are now disabled and disadvantaged and the community in general. These projects often provide access to information and rights and to enhance the status of sufferers and those disabled by illness (Richards, 1983).

On this account voluntary associations performed a subsidiary role, stepping in where state provision was inadequate, helping individuals to exercise their capacities of practical reasoning and to play an active part in the life of the association and their communities-helping individuals to help themselves and each other through transformative relationships of reciprocity. The positive action of LINK/GAMH grew out of practical reasoning about needs, but ultimately the organization was formed in response to structural inequalities which condemned those diagnosed as mentally ill to the status of second-class citizens and which left mental health services as a low priority for resource allocation. Richards (1983) writes:

Voluntary and self-help projects often cater for needs, and encourage aspirations, which are not and perhaps should not be met, or promoted by Statutory Welfare Agencies. Such projects are likely to be innovative, challenging to existing professional practice [...] Such projects also have the ability in some cases to become effective campaigning and pressure groups for better services [...] 
Volunteers, relatives and sufferers often lack confidence in expressing their feelings, ideas and needs because they are encouraged to regard Doctors, Nurses, Social Workers and other professionals as expert and all-knowing. Knowledgeable, sincere and well-trained, most undoubtedly are, but sufferers, consumers, relatives and voluntary carers have the vitally important key to a fuller understanding and response to the experience of illness and disablement.

LINK club members, unlike SUMP members, were not longterm residents of psychiatric hospitals, and for many, the LINK clubs were the only social contact they had and, indeed, the only access to some form of care and support that was available to them. Developing the insight of Erving Goffman that places such as mental hospitals were 'fateful for the inmates' civilian self, Hester Parr (2008, p 17) has argued that in the context of community-based care, possibilities emerged for 'reclaiming a lost or institutionalized "civil self" and that such possibilities were 'partly constituted by inventive uses of mainstream social spaces' (see also Barnes and Shardlow, 1997). In a study of psychiatric patients living 'in the community' in a town in the North of England in the late 1980s, Barham (1998, p 22) found that all the people he interviewed had 'experienced difficulty in surmounting an identity as a "mental patient" and 'their personhood was constantly on probation'. Common concerns of the people Barham had interviewed included 'the barriers to equality with other people, the experience of being made to feel less of a person or an inferior person [...] and the demoralization produced by a health and welfare system that treats them as secondary sort of people or as children' ( $p$ 224). The creation of spaces where marginality was common to former hospital patients living in the community, such as the LINK clubs, made it possible for them to discuss openly and critically their experiences of psychiatric medicine and to support each other to address the common challenges they faced in their lives. Conditions were created and spaces were opened up that allowed patients to participate in social activity and to campaign against the structural injustices which affected them, by means of 'the countervailing power of voluntary social initiative, outside the bureaucratic compass of the state' (Sedgwick, 1982, p 252).

LINK/GAMH operated a practical model of recovery rooted in a practice-based community which addressed the following key questions: '1. Why do you get up in the morning? 2. Where do you lay your head at night? 3 . Where do you get what help, when you need it?' (Richards, 2017). Richards identifies these as 'embodied knowledge' questions, which opened up to further questions:

1. What kind of structured day can you make for yourself? Do you have some satisfying activities that you can do that give you some sense of control and achievement? This means finding something that is 'like work' or some personal project, voluntary activity etc.

2. Have you got a place you call home, where you feel secure, warm, and domestic? Have you got the costs sorted out?

3. What is your friendship network and how do you engage with the 'system' to get the kind of help you need? (Richards, 2017).

A space was designed which was 'divided into three work areas plus a café':

Each area had a designated worker who would fill the walls with information and run groups and consultations on these issues each morning. In the afternoon users were expected to 'buddy up' with someone and go and implement what they wanted to do. They would return for support and continual attempts to get their pattern of life the way they wanted for up to 3 months. Then they would have to take a break and go back just to the LINK group (Richards, 2017).

LINK member Jeanette Deuchars wrote that the LINK clubs members got time for themselves, 'time for healing, time for friendship, time for growth'- 'through the self -help groups I have discovered my own self -worth which will grow in time' (Deuchars, 1990, p 11). Spaces such as those created by LINK/GAMH were the concrete embodiment of what Erving Goffman called 'geographies of licence [...] places pervaded by a feeling of relaxation and selfdetermination' (Goffman, 1961, pp 230-231). Unlike SUMP, which had formed in the locked wards of an old psychiatric hospital, and where the group's activities were limited by the constraints imposed by confinement, LINK/GAMH opened up 'spaces of innovation and contestation' outside of the paternalistic, hospital-dominated system in Scotland (Cresswell and Spandler, 2009, p 140; Spandler, 2006; 2009). Richards reflected that 'psychiatric hospitals in Glasgow were hell holes'. He remembers that 'the health/social work split was a chronic political stand-off and 'the newly created Strathclyde Regional Council became a behemoth with no good policies, low spend and [was] indifferen[t] to the whole issue of "community care"'. 'Psychiatrists', according to Richards, 'were generally wedded to an organic reductionist theory of brain functioning [...] unable to see their patients as people, persons with histories (unique histories [...]), but as bundles of symptoms'. He believed that most psychiatrists 'could never harness the therapeutic and healing energies of the sufferers, or appeal for resources to link with their aspirations' and that 'they lacked the collaborative nuances to blend their expertise and their prescribing and legal responsibilities with the activities of everyday life' (Richards, 2017). He had found that overall hospital-based psychiatric medicine was 'resistant to organizational change' and was 'tied to a limited set of theoretical precepts about the meaning of being a person'--'they had no idea what it was like to be a person in a cultural context with a mental health problem'. He also felt that the so-called 'antipsychiatry' movement associated with Scottish psychiatrist R.D. Laing, which had mounted a critique of psychiatric theory and practice in the 1960s, 'suffered from a lack of real everyday grasp of the lived lives of "mental health service users" ' (Richards, 2017). By forming a civil association outside of the official constraints of the hospital system, but in partnership with supportive professional colleagues within the system who offered space and resources, Richards was able to facilitate the building of new relationships between professionals and service users which had not previously existed, acting as an intermediate subsidiary institution. Through the formation of such associations and relations, LINK/GAMH was able to express and protect the realization by psychiatric patients their capacity for agency in their own lives and in a wider social context, recognizing the need for a nexus of trust and a background of support in a practice-based community, which would enable them to see themselves as responsible agents and to establish enduring social bonds and commitments.

\section{From self-help in Glasgow to a world in action: goodbye to 'being the good obedient patient'}

The Glasgow LINK clubs were advertised in the MIND Information Bulletin for winter 1981/1982 as 'social clubs' which addressed problems such as:

shyness, isolation, loneliness, difficulty in making friends, lack of personal and social confidence, coming to terms with having been mentally ill, and the feelings of guilt, 
shame, fear and sense of stigma which still surround being or having been a psychiatric patient [...] by offering support, care, understanding and a helping hand when members are feeling down, a place to go to and friends to be with as part of an active social life (SA/MIN/B/80/18 A, Wellcome Library).

By 1984 a LINK Education and Action in Mental Health group was gaining recognition for its campaigning activities. Individuals from this group were finding their own voice, and collectively, they began to articulate criticisms of the Scottish mental health system. The group made a presentation to the 1984 AGM of MIND, formerly the National Association for Mental Health, the event at which over 20 years previously Enoch Powell had announced plans to close the old asylums. The conference was named Life After Mental Illness? Opportunities in an Age of Unemployment. In the run up to the conference an editorial of the MIND magazine, OpenMind, stated that 'mental health services have been dealt a gradual, insidious but very serious blow by the enormous increases in unemployment in recent years [...] a major reappraisal is needed if these services are to relate to today's realities' (SA/MIN/B/80/47/1, Wellcome Library). Members of LINK/GAMH had attended the meeting in 1983 and expressed their dismay that there were no presentations by patients, expatients, or those suffering from mental illness. Kennedy (1984, p 6), a LINK member who introduced the presentation, wrote in OpenMind that the 1983 conference 'was totally dominated by professional mental health workers', adding that 'although this year [1984] again was a professionals' talkshop, we were heartened by the warm response we received from the majority of the delegates' (SA/MIN/B/80/47/1, Wellcome Library). Six LINK Club members, Christine Cowan, Charlie Reid, Elvira McLay, John McManus, Vince Edkins and Tam Graham, presented a tape-slide programme to the MIND audience. This 'tape-slide show' involved playing a tape recording whilst a slide show was presented. Members of the group told stories of their own personal journeys through the mental health system, interspersed with critical commentary on government policy and the state of mental health services in Scotland, addressing issues of hospitals, community care, self-help, housing, employment and discrimination. Following the conference, Kennedy (1984/1985, p 6) wrote in OpenMind that LINK/GAMH is run as a partnership, with the most vital emphasis being on "self-help"'. He went on, 'This enables members to act alongside professionals in an effort to get what people need and want, instead of being fobbed off with excuses and inaction' ( $p$ 6). Dispelling any impression that the notion of self-help which LINK members subscribed to was akin to the narrowly individualistic liberal conception understood by the Conservative government, or that of the nineteenth-century Scottish reformer Samuel Smiles' (1859) book of the same name, Kennedy remarked that

adequate mental health provision means more cash and resources. And the most crucial areas to concentrate on are decentralizing services from hospitals to community units; creating the right type of employment for people recovering from mental illness; and most importantly building an atmosphere where everyone-'patients', 'ex-patients', 'consumers'-are treated like people with human rights, feelings and a need for dignity ( $\mathrm{p} 6$ ).

The appearance of the Glasgow group at the MIND conference inaugurated a period in the mid-1980s when MIND, at its AGM in particular, would begin to provide a platform for patients and ex-patients to speak, and a space where new relationships between local self-help and advocacy groups from across the country could form and develop.
Having described the indignities and inadequacies of the treatment she received in hospital, Christine Cowan (1985, p 11) told the MIND audience how she came to be involved in LINK/ GAMH: 'When I came along to LINK I had no friends, I didn't go out anywhere, even to go down to the local shops was a terrible ordeal for me and it wasn't easy for me to go along, but people made me feel welcome'. The LINK/GAMH resource centre and the LINK clubs, which met in local halls and flats, facilitated the development of solidarity, communication and informationsharing (Routledge, 2001, 2003; Spandler, 2006, 2009). For their members the LINK clubs provided valuable social contact. The fact that LINK club members were often isolated and disconnected individuals, some of whom struggled with social interaction and being in public places, made it all the more admirable that they found the courage to share their personal stories on such a public platform as the MIND AGM. Elvira McLay (1985, p 8) told the MIND audience that in a world of unemployment, voluntary work keeps you in contact'. John McManus (1985, p 9) recalled how at weekends he 'took to wandering' by himself, 'drinking too much' and 'building up resentments towards society' (p 9). He 'felt alienated-like an alien' (p 9).

Underlining some of the challenges faced by psychiatric patients and ex-patients living in the community, the group spoke of how access to employment and housing was a pressing need for their members. Unlike the SUMP members who had spent years at Hartwood Hospital, many of the people involved at LINK had experienced shorter hospital stays and faced problems specific to life outside of hospital in wider society. Their problems did not only concern issues of confinement, health and illness, access to treatment, freedom from coercion, or hospital conditions. They also concerned what Peter Barham has described as 'questions of valuation' and 'their place in a moral community' which 'involves in equal measure questions of identity and material questions' (Barham and Hayward, 1991, p 138, 142). Huw Lloyd-Richards had been critically influenced by Barham's book Schizophrenia and Human Value (Barham, 1984). In the presentation to the MIND AGM the LINK members claimed that patients and ex-patients were 'caught in the invalidity benefits trap' and that 'putting ex-patients on long-term fixed benefits is similar to putting them on the dole, it is expensive, unproductive, unhealthy and degrading' (Cowan, 1985, p 7). They recounted a scheme in which LINK/GAMH had created over 100 jobs funded by the Manpower Services Commission, but concluded that these were 'jobs that lead nowhere, since MSC schemes are not designed for recovering ex-patients', and they emphasized that 'many who are recovering or have recovered from a mental illness are capable of work' (Cowan, 1985, p 7). They discussed how 'expatients faced difficulty in finding adequate accommodation', claiming that 'many patients in psychiatric hospitals could be discharged if places in appropriately staffed hostels were available' (p 7). LINK had managed to secure 27 tenancies to enable some members to live independently, but the group spoke of an 'urgent need for more coordination between housing associations, hospitals, social work departments and local housing departments' (p 7).

The presentation concluded with a definition of the concept of self-help as the Educational and Action group had understood it, demanding a 'move away from the abrogation of patients' rights, the confidence and dignity stripping activities so prevalent in psychiatric hospitals today':

Psychiatric patients are people first and foremost and should be respected as such. To this end we would propose an increased role of advocacy and the setting up of patients' councils similar to some of those of European countries. 
The aim should be the achievement of maximum independence, integration into the community and normal living conditions with sufficient support where necessary [...] Provision of access to housing and employment are essential to helping people to rebuild their lives which have been shattered by mental illness.

What we mean by self-help in these and other areas is organising ourselves to get what we need, and doing so on our own terms, and not allowing ourselves to be patronised or led by the nose under any circumstances [...] In our view self-help enables people to regain their self-confidence, their self-respect and gives them the chance to lead their lives with the dignity so often denied by psychiatric services.

(Education and Action in Mental Health Group, 'Life After Mental Illness' video, 1984, OMH).

The LINK presentation to the MIND AGM in 1984 was filmed by Brighton-based social worker Thurstine Bassett. The following year in 1985 Bassett was awarded a grant to produce a training video for health and social care professionals and he travelled to Glasgow to film the Education and Action group on their home turf. Alongside the interviews with the Glasgow group, the film, Speaking From Experience, featured self-help groups in England and patients councils in the Netherlands. In the film Christine Cowan explained her motivations for becoming involved in campaigning:

I'd just like to see the people who look after the mentally ill being made more aware of the rights and needs of psychiatric patients and perhaps being educated to look at patients as human beings [...] We are not encouraged to think about our own treatment. We are not encouraged to challenge how we are looked after. We are usually encouraged to accept our role of being the good obedient patient

('Speaking from experience' training video produced by Thurstine Bassett for ESCATA, 1985, OMH).

Patients from across the UK were getting involved in local selfhelp and advocacy groups and developing links with others further afield. Christine Cowan was enthusiastic about the prospect of linking up with groups from beyond Scotland and the UK at the World Federation for Mental Health (WFMH) congress to be held in Brighton in 1985, where LINK members would get to meet, for the first time, US and European patient groups involved in self-help and campaigning activities. The film Speaking from Experience would be shown at the congress for the first time. WFMH was established in 1948 to encourage the development of mental health services throughout the world by fostering 'world citizenship', and there was a renewed impetus to build international links between national mental health associations in the 1980s (Brody, 1998; Thomson, 1998). Edith Morgan, a former Deputy Director of MIND became Vice President at WFMH in 1979 and served as President from 1985 to 1987. She started publishing a newsletter twice a year 'to inform the European mental health associations' and 'to stimulate the exchange of information' between workers and 'collaboration beyond the country borders' (Van Remoortel, 2010, p 13). Huw LloydRichards was on the Programme Committee of the 1985 WFMH Congress, along with the Director of the Scottish Association for Mental Health (SAMH), Peter Clarke. Others from Scotland were closely involved in WFMH activities in the early 1980s, including G.M. Carstairs, Professor of Psychiatry at the University of Edinburgh, and Professor Gerald Timbury, Physician
Superintendent at Gartnavel Royal Hospital in Glasgow from 1965 to 1980. Richards remembers that Timbury, who was Dean of Postgraduate Medical Education at University of Glasgow from 1980 to 1984, 'protected' him from 'demands from other psychiatrists [in Glasgow] that [LINK/GAMH] be stopped' (Richards, 2017). Timbury was a supporter from within the Scottish psychiatric establishment who recognized that 'psychiatric patients are particularly vulnerable in periods of unemployment and economic recession' (Dr Timbury to Dr D. Reilly, 12 February 1976, HB 13/11/81, Glasgow Royal Archives, quoted in Long, 2013). He believed that the WFMH could 'help coordinate activities of national societies of mental health throughout the world', whilst Carstairs was keen to 'encourage active participation by all our member associations and not only the national ones, and to let these associations which show zeal and energy go ahead with organizing regional workshops or seminars' ('Feedback on the WFMH "Some Directions for the Future" Task Force Paper-November 1978', PP/EDM/B/6/14, Wellcome Library). LINK/GAMH certainly showed such zeal and energy, benefiting from these wider associations, and in turn they were able to contribute to developments elsewhere through their contributions to workshops and seminars in the fora and platforms which MIND and WFMH began to facilitate for patient associations during the 1980s. There can be no doubt that the 1984 MIND AGM presentation was a momentous occasion not only for LINK/GAMH, but for the mental health service user movement more broadly. Peter Campbell, one of the leading figures in the UK movement in recent decades, has remarked that the LINK/ GAMH Education and Action Group 'were the first group of service users I came across which was involved in making a collective contribution to the debate' (Campbell, 1994, p 99). After the 1984 MIND AGM there was an acceleration of coordinated activity within and between different patient groups across the UK and beyond, as new local, national and international organisations were constituted by psychiatric patients and their allies.

Through the WFMH, mental health associations were able to coordinate and complement activities and pool and share their knowledge, allowing them to act in ways that would not have been possible for them by working alone. In her inaugural Presidential Address to the 1985 WFMH Congress, Morgan asserted that, 'the belief from which [community care] springs is that services which intimately affect people's lives should be planned on a local scale with their involvement' (President's Inaugural address, WFMH Congress, Brighton, 16 July 1985, p 3, PP/EDM/ $\mathrm{B} / 6 / 14$, Wellcome Library). In accordance with the principle of subsidiarity, it was thought that 'since they can more easily try things out on a small scale', local associations are 'especially capable of innovation and pioneering activity' and that 'their closeness to local communities enables them to reflect more accurately individual and local needs and ways of meeting them, than larger and remoter structures' ('The development of the voluntary movement in the UK and some questions arising from it' talk by Edith Morgan on the role of mental health associations in Holland 1997, PP/EDM/B/6/14, Wellcome Library). WFMH recognized that while civic and voluntary action not rooted in local and particular concerns would be inadequate, neither would such civil associations be able to operate without working in cooperation and solidarity with other organisations-in short, regional, national and international associations were able to support one another in accordance with the principles of solidarity and subsidiarity in pursuit of the common good. Organisations like MIND and WFMH were able to assist and facilitate the action of local groups such as LINK/GAMH. Morgan stated that 'the Federation's operation should be to bring it closer to its constituencies, to encourage and facilitate involvement and 
participation, to provide opportunities for its member associations to be part of the decision making in the Federation' (President's Inaugural address, WFMH Congress, Brighton, 16 July 1985, p 5, PP/EDM/B/6/14, Wellcome Library). The 1985 WFMH Congress, like the 1984 MIND AGM, was a seminal moment for the mental health service user movement.

Patients and ex-patients from Scotland, the US, Denmark, Italy and the Netherlands attended in Brighton and discussion groups were held on topics such as 'mutual aid/self-help groups for improved mental health and increased citizens' responsibility', 'citizen advocacy and self-help movements' and the 'political economy of mental health' (WFMH/MIND Mental Health 2000: Action Programmes for a World in Crisis 14-19 July 1985 Congress Programme, PP/EDM/13/3/1/11, Wellcome Library). Some English patients who got wind of this event were aggrieved that they had not been invited to attend. Dutch patients at the congress negotiated with the organisers to let the English group into the conference. A Charter was produced during the conference and a section of the charter was written exclusively by patients and ex-patients, given the title, 'Self Determination as a Human Right and Its Implication for Mental Health Services' (Charter Mental Health 2000 Action Programmes for a World in Crisis: Brighton Declarations on the Rights of Mentally Ill People and the Promotion of Mental Health, 1985, PP/EDM/13/3/1/11, Wellcome Library). Judi Chamberlin, a prominent activist from the US Mental Patients movement spoke at a congress session about 'why patients and ex-patients reject paternalism'. Huw Lloyd-Richards (2017) recalls that Judi Chamberlin's book On Our Own: Patient-Controlled Alternatives to the Mental Health System, 'became the Bible for the early LINK groups' (Chamberlin, 1978). In the Charter, the 'Declaration Group for Self and Citizen Advocacy' stated:

We note the contribution of unemployment and of financial and cultural poverty to people's distress [...]

People who already feel helpless, insecure and victimised suffer further loss of dignity, respect, self-worth and personal power in the 'mental health' system.

Advocacy is a process through which individuals and groups articulate and pursue their needs and interests. This process necessarily involves conflict with a 'mental health' system which creates passivity and dependency.

The group proposed:

The reallocation of public finances to create and develop a wide range of non-medical resources for all people in distress $[\ldots]$

Housing needs are primary $[\ldots]$

Provision must be made for re-entry of ex-patients into the labour market, at prevailing wages and at a level commensurate with their education, skills and interests.

A guaranteed minimum income must be provided for all those without work.

(Charter Mental Health 2000, Action Programmes for a World in Crisis: Brighton Declarations on the Rights of Mentally Ill People and the Promotion of Mental Health, 1985, PP/EDM/13/3/1/11, Wellcome Library).

By 1985 Parsons' 'sick role' was subverted and redefined by patients, as they sought to become agents (MacIntyre, 1977). In 1975 the philosopher Alasdair MacIntyre (1977) had suggested that 'we have to redefine the whole concept of the sick role in its relationship to responsibility', that 'we have to invite patients to become active moral agents in an area where they have been passive; patients have to become agents'. Within a few years, psychiatric patients in Glasgow, the city where MacIntyre was born, were realizing in practice what he had advanced in thought. These psychiatric patients and ex-patients were no longer prepared to passively submit, as powerless and isolated individuals, to the authority of the state-licensed psychiatrist. Instead they began to form associations and to see themselves not only as patients, but as citizens with the capacity to act and with the potential to contribute and participate in civic, social, political and economic life. They had formed their own form of medical community with its own shared moral allegiance (MacIntyre, 1977). LINK club members went on to help found Survivors Speak Out, the National Advocacy Network and the Scottish Users Network, all UK-based organisations of national scope, which would continue to express and enact the principles of solidarity and subsidiarity in their associations and action. Whilst Andrew Roberts is right to identify Scottish groups as pioneers in the development of the 'mental health service user movement' in the UK, it is evident that LINK/GAMH had benefited from being part of a broader network of mental health associations and the relationships which had developed across professional and geographical boundaries. They had learned to see their own pursuit of self-determination and individual flourishing as bound up with their shared fate with other people and they had been allowed to grow in the environments created by intermediate associations like GAMH, MIND and WFMH. While GAMH had facilitated collective action by psychiatric patients in pursuit of the common good, LINK members recognized their indebtedness to the committed and courageous leadership provided by Huw LloydRichards, without whom LINK/GAMH would not have started in the first place. On leaving the organization in 1985 members presented Richards with a framed scroll, inscribed To Our Leader. On his departure, the association's Chairman Tom Campbell remarked that Richards'

formidable organising capacities, his concern for the welfare of those with mental health problems, his imagination and vision and his extensive knowledge of the mental health world and the administrative and political environment in which mental health services must struggle to survive, all contributed to the Association's rapid and varied growth (Campbell, 1985).

Community organization of mental health associations depended on mutual aid and reciprocal relationships of give and take, but they also depended on the voluntary sacrifice, commitment and practical wisdom of dedicated individuals like Richards. While the principles of solidarity and subsidiarity only become effective and transformative for individuals when they are put into practice in the context of structures and systems of government, they also require the virtuous qualities of character and leadership of dedicated individuals to make this happen. It must not be forgotten than solidarity and subsidiarity involves a kind of balancing act, whereby individual dignity and the common good are respected and advanced. To return to its historical origins in Aristotle's Nichomachean Ethics (Aristotle, 2000), subsidiarity is rooted in the exercise of practical reason, dependent not on choice or autonomy, but on the virtues of moral agents who exercise this capacity on the basis of their local and particular knowledge and experience (Milbank and Pabst, 2016). In doing so LINK/GAMH were able to defend their communities from the paternalistic excesses of the mental health system and stake their claim, as citizens, to participation in the social and economic life of the nation. 


\section{Conclusion}

In the 1970s and 1980s, when the British economy was in trouble and the mental health services of Scotland were grossly underresourced, the voluntary action of a psychiatric social worker in Glasgow, with the help of supportive colleagues, facilitated the formation of pioneering patient associations and self-help groups. While in many ways Huw Lloyd-Richards was responding to the structural injustices and inequalities within the statutory system of healthcare, a system which accorded a low priority to mental health and forced patients into passive and dependent roles, he was able to create spaces and foster relationships which offered patients a route out of the 'sick role' to civic selfhood and political agency. LINK/GAMH afforded its members opportunities for self-development and deliberation about their common good, allowing psychiatric patients to participate in social and political life, and to determine their needs and how these should be met.

Writing about the history of social psychiatry in the United States context, Smith (2016) recently looked to 'potential solutions that might be beneficial for mental health while simultaneously providing a better balance between individualism and society', concluding that 'if the history of social psychiatry has any lessons in terms of turning theory into practice, it is that pragmatic, practical and nuanced solutions, solutions which balance the human drives to be both community-oriented and individualistic, [...] will be required'. The contention here is that these solutions can be found in the work of LINK/GAMH and other such associations which began to emerge in the 1970s and 1980 s in the UK. Whilst those who participate in such action must be alert to undue interference from the state, these organisations have shown what is possible when people came together in local communities to develop alternatives to the established public authorities on mental health in the pursuit of public goods. Such organisations were characterized by the art of self-government, like the civil associations identified by Alexis de Tocqueville in his Democracy in America, acting as vital buffers against the extremes of individualism, administrative centralization and technocracy (Tocqueville, 2006; Herbert, 2011). Whilst these local groups can never be expected to provide the complete solution to the problems of mental illness, structural injustice and social dislocation-and it must be stressed that the principle of subsidiarity requires that the state provides positive non-dominating support to associations and their members-the social organisation of mental healthcare must operate in accordance with the principle of subsidiarity to ensure that the dignity of individual person is respected, that the patient is empowered, and local democracy and international solidarity is fostered.

As Pope Benedict (2009) has argued, 'the principle of subsidiarity is particularly well-suited to managing globalization and directing it towards authentic human development' and 'the governance of globalization must be marked by subsidiarity, articulated into several layers and involving different levels that can work together'. Through their relationships with mental health associations beyond Glasgow, LINK/GAMH, participated in a global movement for change which sought to redefine the roles and relationships of psychiatric patients in health services and in wider society. One of the most telling incidents which took place at the WFMH congress in 1985 was when UK Health Minister in the Conservative government, Kenneth Clarke, took to the stage to deliver a speech. When $\mathrm{Mr}$ Clarke claimed that the UK were pioneers in community mental health care he was met with boos and shouts. One delegate at the back of the hall shouted, 'How can you talk about mental health when your government has done nothing but increase the rate of unemployment and cut back housing?'
This question received great applause and Clarke responded angrily, complaining that WFMH was not the place for criticisms about housing, unemployment and poverty: 'I don't believe political sloganizing of any kind is going to do anything toward that'. He went on, 'You would be more effective in achieving your aims by reasonable argument. If you keep the few crack pots out of this field so much the better'. Later when Clarke was leaving the conference centre, he was confronted by a delegate and asked to apologize for his intemperate language. Looking angry, Clarke stubbornly reiterated his point: 'I think it is a misuse of an international congress on mental health to try to use it as a political forum. I think it is you who should apologize to this congress for giving routine support to a routine political barracker at the back of the hall' (Nursing Mirror, [page unnumbered] 24 July 1985, PP/EDM/13/3/1/11, Wellcome Library). It seems that Clarke expected people with mental health difficulties to accept their role of 'being the good obedient patient'. While he was right to say that political sloganizing achieves little, he had done just that before he was asked a legitimate and reasonable question of government policy. The use of the term 'crack pot' was an example of people's mental health problems being used in an attempt to discredit them and deny them the status and capacities of rational agency and responsible citizenship. And this at a time when large numbers of patients were disenfranchised. Lord Ennals, a MIND official and former Labour Secretary for Social Services, who chaired the session, said at the end of Clarke's speech that 'I don't think you can separate the effects of housing, poverty and unemployment from mental health' (Nursing Mirror, [page unnumbered] 24 July 1985, PP/EDM/ $13 / 3 / 1 / 11$, Wellcome Library). Few politicians today would deny that the effects of poverty, unemployment and inadequate housing impact upon mental health. But as this episode shows and as the patient politics of subsidiarity have demonstrated, while there are still those who would deny the civic selfhood and political agency of psychiatric patients, solidarity and subsidiarity will continue to be important principles guiding practical solutions to the social and economic problems faced by those diagnosed with mental illness.

Received: 27 November 2017 Accepted: 28 February 2018

Published online: 27 March 2018

\section{References}

Aristotle (2000) Nichomachean Ethics (trans: Crisp R). Cambridge University Press: Cambridge

Aroney N (2014) Subsidiarity in the writings of Aristotle and Aquinas. In: Evans M, Zimmermann A (eds) Global perspectives on subsidiarity. Ius Gentium: comparative perspectives on law and justice. Springer, Dordrecht, vol 37

Barham P (1984) Schizophrenia and human value. Basic Blackwell, Oxford

Barham P (1997) Closing the Asylum: The Mental Patient in Modern Society. Penguin, London

Barham P (1998) From the asylum to the community: the mental patient in postwar Britain. In: Gijswijt-Hofstra M, Porter R (eds) Cultures of psychiatry and mental health care in Postwar Britain and the Netherlands. Rodopi, Amsterdam

Barham P, Hayward R (1991) From the mental patient to the person. Routledge, London

Barnes M, Shardlow P (1997) From passive recipient to active citizen: participation in mental health user groups. J Ment Health 6(3):275-286

Benedict XVI (2009) Caritas in veritate. http://w2.vatican.va/content/benedict-xvi/ en/encyclicals/documents/hf_ben-xvi_enc_20090629_caritas-in-veritate. html. Accessed 16 Nov 2017

Bogg A (2016) Subsidiarity or freedom of association? A perspective from labor law. Am J Jurisprud 61(1):143-174

Brennan PM (2014) Subsidiarity in the tradition of Catholic social doctrine. In: Evans M, Zimmermann A (eds) Global perspectives on subsidiarity. Ius 
Gentium: comparative perspectives on law and justice. Springer, Dordrecht, vol 37

Brody E (1998) The search for mental health: a history and memoir of WFMH 1948-1997. William \& Wilkins, Baltimore

Burnham JC (2012) The death of the sick role. Social Hist Med 25(4):761-776

Campbell P (1994) The contribution of service users in the design and implementation of Mental Health services. In: Christine Dean (ed) A slow train coming: bringing the mental health revolution to Scotland. The Greater Glasgow Community and Mental Health Services Trust, Glasgow

Campbell T (1985) Ring out the old. Inside Out, p 6

Chamberlin J (1978) On our own: patient-controlled alternatives to the mental health system. Hawthorn Books, New York

Charter Mental Health (2000) Action programmes for a world in crisis: Brighton declarations on the rights of mentally ill people and the promotion of mental health, PP/EDM/13/3/1/11. Wellcome Library, London

Cowan C (1985) In the MIND'sEye. Inside Out, p 6

Cresswell M, Spandler H (2009) Peter Sedgwick's legacy for the politics of mental health. Social Theory Health 7:129-147

Deuchars J (1990) A time to weep and a time to heal. Beyond Diagnosis, p 1

Drucker N (1986) Lost in the haar: a critique of Mental Health inFocus. In: David McCrone (ed) Scottish Government Yearbook 1986, University of Edinburgh, Edinburgh

Drucker N (1987a) Creating community mental health services in Scotland: volume I: the issues. SAMH, Edinburgh

Drucker N (1987b) Creating community mental health services in Scotland: volume II: community services in practice. SAMH, Edinburgh

Education and Action in Mental Health Group, 'Life After Mental Illness' video, filmed by Thurstine Bassett at MIND AGM, 1984, and 'Speaking from Experience' training video produced by Thurstine Bassett for ESCATAEast Sussex Consultancy and Training Agency) 1985, both recordings held at the Oor Mad History project, based at the Consultation and Advocacy Promotion Service (CAPS) (Old Stables, Eskmills Park, Station Road, Musselburgh, $\mathrm{EH} 217 \mathrm{PQ})$

Feedback on the WFMH (1978)Some directions for the future. Task Force Paper, $\mathrm{PP} / \mathrm{EDM} / \mathrm{B} / 6 / 14$, Wellcome Library

Finnis J (2011) Natural law and natural rights, 2d edn. Oxford University Press, Oxford

Finnis J (2016) Subsidiarity's roots and history: some observations. Am J Jurisprud 61(1):133-141

Gallagher M (2017) From asylum to action in Scotland: the emergence of the Scottish Union of Mental Patients, 1971-1972. Hist Psychiatry 28 (10):101-114

Goffman E (1961) Asylums: essays on the social situation of mental patients and other inmates. Anchor Books, New York

Gulstad J (1987) The right to be ordinary: a study of obstacles and achievements in community care in Scotland. Glasgow Special Housing group, Glasgow

Hannah B (1990) Finding my voice. Beyond Diagnosis, p 1

Herbert LJ (2011) Tocqueville's 'administrative decentralization' and the Catholic principle of subsidiarity. Cathol Social Sci Rev 16:241-258

John XXIII (1961) Mater et Magistra. http://w2.vatican.va/content/john-xxiii/en/ encyclicals/documents/hf j-xxiii_enc_15051961_mater.html.. Accessed 16 Nov 2017

Kennedy G (1984) Piecing a life together. OpenMind, p 12

Letter from Dr G (1976) Timbury to Dr D. Reilly, 12 February, HB 13/11/81, Glasgow Royal Archives

Long V (2013) Rethinking post-war mental health care: industrial therapy and the chronic mental patient in Britain. Social Hist Med 26(4):738-758

Long V (2017) 'Heading up a blind alley'? Scottish psychiatric hospitals in the era of deinstitutionalization. Hist Psychiatry 28(10):115-128

MacIntyre A (1977) Patients as agents. In: Spicker SF, Tristram Engelhardt H Jr (eds) Philosophical medical ethics, its nature and significance. Proceedings of the third trans-disciplinary symposium on philosophy and medicine, Farmington, Connecticut, 11-13 December 1975. D. Reidel Pub. Co., Farmington, Connecticut

Martin FM (1984) Between the acts: community mental health services 1959-1983. Nuffield Provincial Hospitals Trust, London

Maxwell C (1987) The role of the voluntary sector. In: Drucker N (ed.) Creating community mental health services: volume I: the issues. SAMH, Edinburg

McLay, E (1985) In the MIND'sEye. Inside Out, p 6

McManus, J (1985) In the MIND'sEye. Inside Out, p 6

Mental Welfare Commission for Scotland (MWCS) (1975) No place to go: an account of the work of the commission since the publication of 'A Duty to Care' in 1972. HMSO, Edinburgh

Mental Welfare Commission for Scotland (MWCS) (1981) Does the patient come first? An account of the work of the Mental Welfare Commission for Scotland between 1975 and 1980. HMSO, Edinburgh
Milbank J, Pabst A (2016) The politics of virtue: post-liberalism and the human future. Rowman \& Littlefield International Ltd., London

MIND Information Bulletin (1981-1982) SA/MIN/B/80/18A, Wellcome Library

Morgan E (1985) President's inaugural address. WFMH Congress, Wellcome Library, Brighton

Morgan E (1997) The development of the voluntary movement in the UK and some questions arising from it. Welcome Library, Holland

Nicolson M (2002) Commentary: Nicholas Jewson and the disappearance of the sick man from medical cosmology, 1770-1870. Int J Epidemiol 38(3):639-642

Nicolson M, Lowis G (2002) The early history of the multiple sclerosis society of Great Britain and Northern Ireland: a socio-historical study of lay/practitioner interaction in the context of a medical charity. Med Hist 4:141-174

Nursing Mirror (1985) PP/EDM/13/3/1/11, Wellcome Library

OpenMind (1984) SA/MIN/B/80/47/1, Wellcome Library

OpenMind (1984-1985)Living on the Breadline, No. 12, SA/MIN/B/80/47/1, Wellcome Library

Parr H (2008) Mental health and social space: towards inclusionary geographies. Blackwell, Oxford

Parsons T (1951) The social system. Free Press, New York

Pius XI (1931) Quadragesimo Anno. http://w2.vatican.va/content/pius-xi/en/ encyclicals/documents/hf_p-xi_enc_19310515_quadragesimo-anno.html. Accessed 16 Nov 2017

Richards HL (1983) Mental health projects in Glasgow. LINK/GAMH, Glasgow

Richards HL (2017) Personal communication with author. Correspondence attached and enclosed in email dated 16 November

Roberts A (2009) Scotland the brave Ment Health Today 9(6):16-18

Routledge P (2001) Convergent space and fluidity of networks. In: Colin Barker and Clyde Tyldesley (eds) Alternative futures and popular protest: Seventh international Conference, 17-19 April 2001, Vol. 11. Manchester Metropolitan University, Manchester

Routledge P (2003) Convergence space: process geographies of grassroots globalization networks. Transactions of the Institute of British Geographers (28) 333-349

Schumacher EF (1989) Small is beautiful: economics as if people mattered. Harper Perennial, New York

Sedgwick P (1982) Psychopolitics. Pluto Press, London

Smiles S (1859) Self-help: with illustrations of character and conduct. John Murray, London

Smith M (2016) A fine balance: individualism, society and the prevention of mental illness in the United States, 1945-1968. Palgrave Commun 2:16024. https:// doi.org/10.1057/palcomms.2016.24

Spandler H (2006) Asylum to action: Paddington Day Hospital, therapeutic communities and beyond. Jessica Kingsley, London

Spandler H (2009) Spaces of psychiatric contention: a case study of a therapeutic community. Health Place 15:672-673

Survivors History (2017). http://www.studymore.org.uk/mhhglo.htm\#mental patientsunions. Accessed 16 Nov 2017

Thomson M (1998) Before anti-psychiatry: 'mental health' in wartime Britain. In: Gijswijt-Hofstra M, Porter R (eds) Cultures of psychiatry and mental health care in postwar Britain and the Netherlands. Rodopi, Amsterdam

Tocqueville A (2006) Democracy in America. (Mayer JP (ed.); trans: Lawrence G). Harper Perennial Modern Classics, New York

Tomlinson J (2016) De-industrialization not decline: a new meta-narrative for post-war British history. Twent-Century Br Hist 27(1):76-99

Van Remoortel J (2010) History of mental health Europe 1985-2010. Mental HealthEurope-Santé, Mentale Europe Brussels

WFMH/MIND Mental Health (2000) Action programmes for a world in crisis, 14-19 July 1985, Congress Programme, PP/EDM/13/3/1/11, Wellcome Library

\section{Acknowledgements}

I am particularly grateful to Dr Huw Lloyd-Richards for agreeing to correspond with me on the history of LINK/GAMH. My thanks are due also to the Oor Mad History project and the Wellcome Library, for making available a large proportion of the primary source material upon which this research was based.

\section{Additional information}

Competing interests: The author declares no competing financial interests.

Reprints and permission information is available online at http://www.nature.com/ reprints

Publisher's note: Springer Nature remains neutral with regard to jurisdictional claims in published maps and institutional affiliations. 
(c) (i) Open Access This article is licensed under a Creative Commons Attribution 4.0 International License, which permits use, sharing, adaptation, distribution and reproduction in any medium or format, as long as you give appropriate credit to the original author(s) and the source, provide a link to the Creative Commons license, and indicate if changes were made. The images or other third party material in this article are included in the article's Creative Commons license, unless indicated otherwise in a credit line to the material. If material is not included in the article's Creative Commons license and your intended use is not permitted by statutory regulation or exceeds the permitted use, you will need to obtain permission directly from the copyright holder. To view a copy of this license, visit http://creativecommons.org/ licenses/by/4.0/.

(C) The Author(s) 2018 